\title{
Energy expenditure (EE) in mechanically ventilated patients: espen equation using different body weights (BW) vs. indirect calorimetry (IC)
}

\author{
S Graf ${ }^{1,2}$, L Genton², T Oshima2 2 C Pichard ${ }^{2}$, CP Heidegger ${ }^{3^{*}}$ \\ From ESICM LIVES 2015 \\ Berlin, Germany. 3-7 October 2015
}

\section{Introduction}

IC is the reference method to measure EE, but is not available in every healthcare center. ESPEN guidelines recommend using a predictive equation based on the BW before acute illness in case of fluid retention, but the accuracy of this $\mathrm{BW}$ is questionable.

\section{Objectives}

The aim of this study is to ascertain the accuracy of the ESPEN equation using different BW vs. EE measured by IC, in ventilated patients and to determine the most suitable BW.

\section{Methods}

All mechanically ventilated patients staying $>72 \mathrm{~h}$ in ICU, with Fi0 $2<60 \%$, PEEP $<9 \mathrm{cmH}_{2} \mathrm{O}$, no pulmonary fistula or lung multi-resistant bacteria were included and had IC measurement. We calculated EE with the ESPEN equation (20-25 kcal/ $\mathrm{kg}$ acute phase and 25-30 $\mathrm{kcal} / \mathrm{kg}$ post-acute phase), using several BW: anamnestic $\left(\mathrm{BW}_{\mathrm{AN}}\right)$, measured $\left(\mathrm{BW}_{\mathrm{MES}}\right)$, adjusted for water balance $\left(\mathrm{BW}_{\mathrm{ADJ}}\right)$ and ideal $\mathrm{BW}$ calculated for a body mass index of 22.5 and $25 \mathrm{~kg} / \mathrm{m}^{2}$. Results are presented as mean \pm SD. Calculated EE was compared to EE measured by IC, with ANOVA repeated measure and Bonferroni posthoc test, as well as Bland-Altman analysis.

\section{Results}

We included 85 patients $(57 \pm 19$ y, 61 men, SAPS II $50 \pm$ 14 ), including 47 in acute phase. EE calculated with $\mathrm{BW}_{\mathrm{AN}}, \mathrm{BW}_{\mathrm{ADJ}}$ and $\mathrm{BW}$ MES significantly overestimated measured EE by IC $(1910 \pm 458 \mathrm{kcal} / \mathrm{d}$; $\mathrm{p}<0.0001)$.

${ }^{3}$ Hopitaux Universitaires de Geneve, Geneve 14, Switzerland

Full list of author information is available at the end of the article
Table 1. Differences of EE according to various BW

\begin{tabular}{ll}
\hline $\begin{array}{l}\text { ESPEN } \\
\text { equation }\end{array}$ & $\begin{array}{l}\text { Mean } \boldsymbol{\Delta} \text { (calculated- measured EE) }(\mathbf{\pm 2 S D})^{*} \mathbf{p}<\mathbf{0 . 0 5} \\
\text { Bonferroni post hoc test }\end{array}$ \\
\hline BWAN & $271(-1273 ; 731)^{*}$ \\
\hline BWADJ & $265(-1339 ; 809)^{*}$ \\
\hline BWMES & $368(-1478 ; 742)^{*}$ \\
\hline BWBMI22.5 & $-15(-811 ; 841)$ \\
\hline BWBMI25 & $195(-1041 ; 651)$ \\
\hline
\end{tabular}

Differences of calculated EE were statistically significant between the various BW used $(\mathrm{p}<0.0001)$.

\section{Conclusions}

It is crucial to define the best BW to be used because it impacts calculated EE. The ideal BW calculated for a BMI at $22.5 \mathrm{~kg} / \mathrm{m}^{2}$ matches better with measured EE than other BW. ESPEN equation is not accurate enough to be used in a metabolically heterogeneous ICU population. It tends to overestimate the EE increasing the risk of overnutrition and potential negative impact on clinical outcome.

\section{Authors' details}

'Geneva University Hospital, Adult Intensive Care, Geneva, Switzerland. ${ }^{2}$ Geneva University Hospital, Nutrition Unit, Geneva, Switzerland. ${ }^{3}$ Hopitaux Universitaires de Geneve, Geneve 14, Switzerland.

Published: 1 October 2015

doi:10.1186/2197-425X-3-S1-A293

Cite this article as: Graf et al:: Energy expenditure (EE) in mechanically ventilated patients: espen equation using different body weights (BW) vs. indirect calorimetry (IC). Intensive Care Medicine Experimental 2015 3(Suppl 1): A293.
(C) 2015 Heidegger et al.; This is an Open Access article distributed under the terms of the Creative Commons Attribution License (http://creativecommons.org/licenses/by/4.0), which permits unrestricted use, distribution, and reproduction in any medium, provided the original work is properly cited. 